\title{
Nutritional status and specific leaf area of mahogany and tonka bean under two light environments.
}

\author{
José Francisco de C. GONÇALVES ${ }^{1}$, Gil VIEIRA ${ }^{1}$, Ricardo A. MARENCO ${ }^{1}$, João Baptista S. FERRAZ ${ }^{1}$, \\ Ulysses Moreira dos Santos JUNIOR ${ }^{1}$ and Francisco Cleber F. BARROS ${ }^{2}$
}

\begin{abstract}
Studies on nutritional status and leaf traits were carried out in two tropical tree species Swietenia macrophylla King (mahogany) and Dipetryx odorata Aubl. Willd. (tonka bean) planted under contrasting light environments in Presidente Figueiredo-AM, Brazil. Leaves of $S$. macrophylla and $D$. odorata were collected in three year-old trees grown under full sunlight (about $2000 \mu$ mol $\mathrm{m}^{-2} \mathrm{~s}^{-1}$ ) and natural shade under a closed canopy of Balsa-wood plantation (Ochroma pyramidale Cav. Ex. Lam.Urb) about 260 $\mu \mathrm{mol} \mathrm{m} \mathrm{m}^{-2}$. The parameters analysed were leaf area (LA), leaf dry mass (LDM), specific leaf area (SLA) and leaf nutrient contents. It was observed that, S. macrophylla leaves grown under full sunlight showed LA 35\% lower than those grown under shade. In D. odorata leaves these differences in LA were not observed. In addition, it was observed that $S$. macrophylla shade leaves, for LDM, were $50 \%$ smaller than sun leaves, while in D. odorata, there differences were not observed. SLA in S. macrophylla presented that sun leaves were three times smaller than those grown under shade. In $D$. odorata, no differences were observed. Nutrient contents in S. macrophylla, regardless of their light environments, showed higher contents for P and Ca than those found in D. odorata. The N, K, Fe and Mn contents in S. macrophylla leaves decreased under shade. Finally, we suggest that the decreasing in leaf nutrient contents may have a negative influence on leaf growth. The results demonstrated that the tested hypothesis is true for leaf traits, which $D$. odorata, late-successional species, showed lower plasticity for leaf traits than Swietenia macrophylla, mid-successional species.
\end{abstract}

\section{KEY WORDS}

tropical species, leaf traits, nutrients, forest succession.

\section{Estado nutricional e área foliar específica de mogno e cumaru sob dois ambientes de luz.}

\begin{abstract}
RESUMO
Estudou-se a nutrição mineral e as características foliares de duas espécies arbóreas tropicais Switenia macrophylla King (mogno) e Dipteryx odorata Aubl Willd (cumaru) plantadas sob dois ambientes de luz em Presidente Figueiredo-AM, Brasil. Folhas de S. macrophylla e de D. odorata, com três anos de idade, crescidas em plantio a céu aberto (sol) com cerca de 2000 umol $m^{-2} s^{1}$ e sob cobertura natural (sombra) de plantas de pau-de-balsa (Ochroma pyramidale Cav. Ex Lam. Urb) com cerca de 260 $\mu \mathrm{mol} \mathrm{m} \mathrm{s}^{-1}$, foram analisadas quanto à área foliar ( $\mathrm{AF}$ ), a mass a da matéria seca (MMS), a área foliar específica (AFE) e aos teores de nutrientes foliares. Verificou-se que, folhas de S. macrophylla, crescidas a pleno sol, apresentaram AF $35 \%$ menor quando comparadas com as folhas crescidas na sombra. Por outro lado, nas folbas de D. odorata, não foram observadas diferenças para AF entre os ambientes. Adicionalmente, observou-se que folhas de sombra de S. macrophylla, com base na MMS, foram $50 \%$ menores que as folhas de sol, enquanto que no D. odorata não foram observadas diferenças para MMS entre os ambientes. Quanto a AFE, nas folhas de S. macrophylla, verificou-se que as follhas de sol foram três vezes menores quando comparadas com as folhas de sombra, e não houve diferença nas folhas do D. odorata. Quanto aos teores dos nutrientes verificou-se que, independentemente do ambiente, folhas de S. macrophylla apresentaram maiores teores de $\mathrm{P}$ e Ca do que aqueles encontrados nas folhas do D. odorata. Os teores de $N, K$, Fe e Mn diminuíram nas folhas de S. macrophylla crescidas a sombra. Por último, nós sugerimos que a diminuição no teor dos nutrientes foliares pode ter influência negativa sobre o crescimento foliar. Os resultados demonstram que a hipótese testada é verdadeira para características foliares, D. odorata, classificada como clímax, exibiu menor plasticidade para características foliares quando comparada com $\mathrm{S}$. macrophylla, classificada como intermediária.
\end{abstract}

\section{PALAVRAS-CHAVE}

espécies tropicais, características foliares, nutrientes, sucessãoflorestal.

\footnotetext{
${ }^{1}$ Instituto Nacional de Pesquisas da Amazônia, Coordenação de Pesquisas em Silvicultura Tropical, Caixa Postal 478, 69011-970 Manaus, AM. *Corresponding author Email: jfc@inpa.gov.br

${ }^{2}$ Estudante de mestrado, programa de Biotecnologia-Universidade do Estado do Amazonas.
} 


\section{ACTA AMAZONICA}

NUTRITIONAL STATUS AND SPECIFIC LEAF AREA OF MAHOGANY

AND TONKA BEAN UNDER TWO LIGHT ENVIRONMENTS.

\section{INTRODUCTION}

Development policies through the last decades in the Amazon were focused preferentially on agricultural projects. The consequences of this practice, today, is reflected on large areas of degraded land due to abandoned pastures, predatory logging and mining (Fearnside, 1999; Nepstad et al., 1999; Laurance et al., 2001). Between 2001-2004 approximately 6.7 millions of hectares were deforested (INPE, 2004).

Increasing rates of deforestation in the tropics, particularly in Amazon region, have created significant pressure to find alternatives to deforestation that are economically competitive. Selective logging where isolated large trees are logged, is one management strategy that might shift the economic balance away from land uses that require clear cut and toward land uses that maintain healthy forests (Bushbacher, 1990). To be an attractive alternative to clear for the conservationist as forests, decreasing the pressure in some native species is important to implement sustainable projects of forest plantations.

Few are the projects to restore these degraded lands in the Amazon region, due to the difficulties to set up mixed stands with native species from different successional status. In recent years studies with tropical tree species have received more attention (Ferraz et al., 2000, Serigatto, 2000; Silva, 2000). However, few of them have addressed the ecophysiological understanding of Amazonian species. Foresters need to know how the species behave in different conditions of soil, microclimate and biological interactions. A better knowledge in foraging strategies for primary resources such as water, nutrients, sun radiation, temperature and $\mathrm{CO}_{2}$ will facilitate the manipulation of these species in managed ecosystems such as those found in planted forest stands.

Swietenia macrophylla King (Meliaceae) and Dipteryx odorata Albl. Willd. (Fabaceae) are species found in Amazon region (Ribeiro et al., 1999). Swietenia macrophylla (mahogany) is a mid-successional species and is a valuable neotropical timber species which suffer intense pressure due the selective logging. (Lorenzi, 1998). Dipteryx odorata (tonka bean) is a late-successional species, which has many industrial uses such as timber, medicinal properties and essential oil (cumarin) (Lorenzi, 1998).

Some authors have hypothesized that mid-successional species have greater physiological and morphological plasticity than late-successional species in response to environmental changes (Bazzaz 1979, Bongers et al. 1988). To test this hypothesis on studies with local species (Vieira, 1996; Marenco et al., 2001; Gonçalves et al., 2001), that late-successional species (Dipteryx odorata) are less plastic than mid-successional (Swietenia macrophylla) for leaf traits, we focused on the interactions between primary resources (light) related to tree growth in a mixed forest plantation in a degraded abandoned agricultural field. The objectives of our study were analyzing leaf allometry and leaf nutrient contents to acquire a better understanding related to leaf growth allometry and nutrient versus irradiance interactions.

\section{MATERIALS AND METHODS}

This study was conducted in an experimental plantation near Presidente Figueiredo in the Brazilian Amazon (01 $51^{\circ} \mathrm{S}$; $\left.60^{\circ} 04^{\prime} \mathrm{W}\right)$. Mean annual temperature is about $27^{\circ} \mathrm{C}$ and annual precipitation ranges from 1750 to $2500 \mathrm{~mm}$. The soil is an oxisol, and $\mathrm{pH}$ ranges from 3.9 to 4.6 . The area had been an abandoned agricultural field for about eight years and a mixed plantation was set up in May 1998 following a "quincôncio" system (one slow growth successional species neighbored by four fast growth pioneer). Seedlings from both species (mahogany and tonka bean) were planted in holes spaced $3 \times 3 \mathrm{~m}$ apart. The seedlings were grown under shade $\left(260 \mathrm{mmol}\right.$ photons $\left.\mathrm{m}^{-2} \mathrm{~s}^{-1}\right)$ and full sunlight about $2000 \mathrm{mmol}$ photons $\mathrm{m}^{-2} \mathrm{~s}^{-1}$ at open sky. Shade was produced by balsa wood canopy (Ochroma pyramidale Cav. Ex Lam. Urb). We collected data for this study from threeyear-old saplings either grown under balsa wood canopy or in an open site. Mahogany saplings were $1.1 \mathrm{~m}$ tall, whereas tonka been saplings were $4.30 \mathrm{~m}$ in height. By the time data were collected, the balsa wood was about $11.1 \mathrm{~m}$ height and $15-20 \mathrm{~cm}$ DBH (diameter at breath height) and the leaf area index of its foliage (optically determined) was 2.46 (Li-Cor Model 2050, Lincoln, NE USA) with $13 \%$ of full sunlight about $260 \mu \mathrm{mol}$ photons $\mathrm{m}^{-2} \mathrm{~s}^{-1}$. The fertilization in the hole was a mixture of soil + 150 g (N-P-K 4-6-8 + limestone 3:1).

The data set for leaf area (LA), leaf dry mass (LDM), specific leaf area (SLA) and macro and micronutrient contents were collected from five fully expanded leaves for each of 10 trees grown in contrasting sun environments. Leaf area was determined by using a leaf area meter (Li-Cor model 3000), Lincoln, NE USA). LDM was determined after drying in $75^{\circ} \mathrm{C}$ until constant mass. SLA was determined by leaf area $\left(\mathrm{cm}^{2}\right) /$ dry mass (g) ratio. Nutrient contents were determined using leaf dried mass. Nitrogen contents were determined by the Kjeldahl method. Phosphorus contents in the nitro-perchloric mixture were determined by using the ammonium molybdate method (Murphy \& Riley, 1965). In the same extract, $\mathrm{Ca}, \mathrm{Mg}, \mathrm{K}, \mathrm{Fe}, \mathrm{Zn}$, $\mathrm{Cu}$ and $\mathrm{Mn}$ contents were determined by atomic absorption spectrophotometry (Perkin Elmer 1100B, Uberlingen, Germany) as described by Miyazawa et al. (1999).

The data were collected in randomly chosen samples and were analyzed in a two-way ANOVA: two species (mahogany and tonka bean) by two light environments (shade $x$ sun) with six replicates. The means were compared using the Tukey test $(\mathrm{P} \leqslant 0.05)$.

\section{RESULTS AND DISCUSSION}

Mahogany leaves showed differences in leaf area and dry mass in response to the two tested light environments $(\mathrm{P}<0.01)$. The area of mahogany leaves in plants grown under shade was $35 \%$ greater than those grown under full sunlight. For leaf dry mass, it was observed that shade leaves were 56\% greater than those grown under full sunlight (Table 1). On the contrary, tonka bean did not change their leaf traits for both parameters leaf area and dry mass in contrasting light environments. However, the environmental influences tonka 


\section{ACTA AMAZONICA}

bean and mahogany leaves, for leaf area, were always larger in shade than in full sunlight.

Analyzing the specific leaf area ratio (SLA), both species behaved similarly in terms of leaf biomass allocation, but the order of magnitude was different. Mahogany leaves were heavier in a sun environment than in shade. For tonka bean no significant differences were detected. The SLA in mahogany grown under full sunlight was three times smaller than those grown under shade. Comparison between the two species, it was observed that mahogany presented SLA values about $83 \%$ greater than tonka bean and $43 \%$ smaller than tonka bean in the shade and full sunlight, respectively. In addition, it was observed that the difference for SLA in mahogany leaves comparing the light environment, was three times greater in shade than in full sunlight, while for tonka bean leaves this difference was just $13 \%$. These results suggest that mahogany (mid-successional) presented greater phenotypic plasticity than tonka bean for leaf area, leaf mass and specific leaf area.

Through leaf allometric relations it is possible to use leaf size as an indicator of plant response to light environment. For example, in a study with mahogany and tonka bean Marenco et al. (2001) found similar results in SLA, which the values were greater in shade than in full sunlight. Nevertheless, some mean values differed to the results founded by Marenco et al. (2001) with these species. It is likely that the environment factors were an influence (e.g. rainfall), due to different data collecting period.

SLA as a single factor is not a good predictor ofleafmorphological plasticity due to multi-factorial influences that occur during the leaf life-span, such as light environment, nutrients, temperature and water supply (Turner \& Jones, 1980; Schulze, 1986).

The greatest values for nitrogen, potassium, iron and manganese concentrations for mahogany trees were observed in grown under full sunlight (Table 2 and 3). In these leaves the interaction between light and nutrient contents may have directly influenced the final size. These four nutrient elements are involved in the photosynthetic processes (e.g. $\mathrm{CO}_{2}$ assimilation), consequently, it may have a greater biomass production. Furthermore, the greater potassium concentration also may have contributed to the stomata regulation, controlling $\mathrm{CO}_{2}$ absorption and water loss. The first hypothesis seems to be consistent when we analyze the results found by Marenco et al. (2001), sun leaves of mahogany had greater

Table 1 - Leaf area (LA), leaf dry mass (LDM) and specific leaf area (SLA) in mahogany and tonka bean grown under two light environments.

\begin{tabular}{lcccccc}
\hline \hline & \multicolumn{2}{c}{ Mahogany } & \multicolumn{2}{c}{ Tonka bean } & & \\
\hline & Shade & Sun & Shade & Sun & F ratio & P value \\
\hline Area $(\mathrm{cm} 2)$ / leaf & $71.2 \pm 8.8 \mathrm{Ab}$ & $45.9 \pm 5.0 \mathrm{Bb}$ & $198.9 \pm 41.3 \mathrm{Aa}$ & $168.8 \pm 22.8 \mathrm{Aa}$ & 11.8 & $<0.01$ \\
Mass $(\mathrm{g}) /$ leaf & $0.4 \pm 0.1 \mathrm{Bb}$ & $0.8 \pm 0.1 \mathrm{Ab}$ & $2.1 \pm 0.5 \mathrm{Aa}$ & $2.0 \pm 0.4 \mathrm{Aa}$ & 187.9 & $<0.01$ \\
SLA $(\mathrm{cm} 2 . \mathrm{g}-1)$ & $178.0 \pm 5.4 \mathrm{Aa}$ & $57.4 \pm 7.8 \mathrm{Bb}$ & $97.4 \pm 16.1 \mathrm{Ab}$ & $85.9 \pm 1.22 \mathrm{Aa}$ & 18.5 & $<0.01$ \\
\hline \hline
\end{tabular}

* Mean \pm standard deviation of six replications. Mean values, followed by the same capital letters within a row for environments and lower case letter for species, are not different at $\mathrm{P}<0.05$ using Tukey test.

Table 2 - Macronutrient contents $\left(\mathrm{g} \mathrm{kg}^{-1}\right)$ in mahogany and tonka bean leaves grown under two light environments.

\begin{tabular}{lcccccc}
\hline \hline & \multicolumn{2}{c}{ Mahogany } & \multicolumn{2}{c}{ Tonka bean } \\
\hline Nutrient & Shade & Sun & Shade & Sun & F ratio & P value \\
\hline Nitrogen & $15.9 \pm 0.5 \mathrm{Bb}$ & $18.1 \pm 0.6 \mathrm{Aa}$ & $20.0 \pm 0.9 \mathrm{Aa}$ & $18.8 \pm 0.6 \mathrm{Aa}$ & 37.7 & $<0.01$ \\
Phosphorus & $1.9 \pm 0.1 \mathrm{Aa}$ & $1.82 \pm 0.04 \mathrm{Aa}$ & $1.7 \pm 0.1 \mathrm{Ab}$ & $1.5 \pm 0.1 \mathrm{Ab}$ & 113 & $<0.01$ \\
Potassium & $3.7 \pm 0.3 \mathrm{Ba}$ & $5.51 \pm 0.5 \mathrm{Aa}$ & $4.1 \pm 1.3 \mathrm{Ba}$ & $6.5 \pm 1.0 \mathrm{Aa}$ & 35.6 & $<0.01$ \\
Calcium & $7.6 \pm 0.4 \mathrm{Aa}$ & $7.87 \pm 0.5 \mathrm{Aa}$ & $3.4 \pm 1.1 \mathrm{Ab}$ & $3.2 \pm 0.7 \mathrm{Ab}$ & 209.4 & $<0.01$ \\
Magnesium & $1.3 \pm 0.1 \mathrm{Aa}$ & $1.1 \pm 0.1 \mathrm{Aa}$ & $0.7 \pm 0.1 \mathrm{Bb}$ & $1.2 \pm 0.1 \mathrm{Aa}$ & 294.7 & $<0.01$ \\
\hline \hline
\end{tabular}

* Mean \pm standard deviation of six replications. Mean values, followed by the same capital letters within a row for environments and lower case letter for species, are not different at $\mathrm{P}<0.05$ using Tukey test.

Table 3 - Micronutrient contents (mg.kg-1) in mahogany and tonka bean leaves grown under two light environments.

\begin{tabular}{lcccccc}
\hline \hline \multicolumn{2}{c}{ Mahogany } & \multicolumn{2}{c}{ Tonka bean } \\
\hline Nutrient & Shade & Sun & Shade & Sun & F ratio & P value \\
\hline Iron & $176.5 \pm 0.3 \mathrm{Ba}$ & $327.5 \pm 4.6 \mathrm{Aa}$ & $192.4 \pm 1.1 \mathrm{Aa}$ & $207.4 \pm 2.5 \mathrm{Ab}$ & 76.8 & $<0.01$ \\
Zinc & $14.9 \pm 0.9 \mathrm{Ab}$ & $15.7 \pm 1.5 \mathrm{Ab}$ & $21.7 \pm 0.8 \mathrm{Aa}$ & $18.6 \pm 3.7 \mathrm{Aa}$ & 31.1 & $<0.01$ \\
Copper & $7.4 \pm 0.8 \mathrm{Aa}$ & $6.1 \pm 0.1 \mathrm{Aa}$ & $4.4 \pm 0.4 \mathrm{Ab}$ & $5.1 \pm 0.9 \mathrm{Aa}$ & 22.5 & $<0.01$ \\
Manganese & $16.2 \pm 0.3 \mathrm{Bb}$ & $22.6 \pm 0.8 \mathrm{Ab}$ & $77.0 \pm 2.1 \mathrm{Ba}$ & $174.3 \pm 0.4 \mathrm{Aa}$ & 3114.8 & $<0.01$ \\
\hline \hline
\end{tabular}

* Mean \pm standard deviation of six replications. Mean values, followed by the same capital letters within a row for environments and lower case letter for species, are not different at $\mathrm{P}<0.05$ using Tukey test. 
photosynthetic rates, sugar and starch concentrations than those in shade environments. However, we did not observe any differences in water-use- efficiency between environments.

In mahogany, shade leaves showed lower $\mathrm{N}$ and $\mathrm{K}$ concentration (Table 2). According to Gillespie and Chaney (1989) the consequence of $\mathrm{N}$ deficiency is a decreasing in leaf size and growth rates. Whereas in tonka bean, the $\mathrm{Mg}$ concentration decreased $43 \%$ in leaves grown under shade. These results can explain the differences found for total leaf chlorophyll in shade leaves in comparison to sun leaves $(2.45$ versus 3.93) observed in this species (Gonçalves et al., 2001.). $\mathrm{Mg}$ is a structural element of chlorophyll molecule, linkage agent of ribosomal sub-unit and enzymatic activator of several enzymes of the photosynthetic machinery (Marschner, 1995). Consequently, leaves with low Mg contents tend to have also lower chlorophyll contents.

When we compare species regardless of their light environments, $\mathrm{P}$ and $\mathrm{Ca}$ always were greater in mahogany leaves. The greater values of Ca content in mahogany could be explained due the greater transpiration rate in this species when compared with tonka bean (Marenco et al., 2001). In a study with nutrient distribution throughout mahogany plants, Schmidt et al. (1999) found highlighted P and Ca and greater amount of $\mathrm{Mg}$ in senescent leaves. They also emphasized the high demand for nutrient in young plants. On the other hand, tonka bean showed greater $\mathrm{Zn}$ and $\mathrm{Mn}$ concentrations than those found in mahogany (Table 3). The mean Mn values (125.7 $\mathrm{mg} \mathrm{kg}^{-1}$ ) found in tonka bean were higher than those found in Ceiba pentandra $\left(13.7 \mathrm{mg} \mathrm{kg}^{-1}\right)$ and lower than those observed in young and old leaves of Virola surinamensis $\left(279.4 \mathrm{mg} \mathrm{kg}^{-1}\right)$ grown in a plantation of impoverished soil in the Central Amazon (Neves et al. 1999).

In the analysis of micro-nutrients contents in mahogany leaves, only Fe and Mn were $46 \%$ and $29 \%$ smaller, respectively, when they grown under shade. Other nutrients did not change. Tonka bean leaves grown under shade decreased $56 \%$ its Mn contents, while other nutrients did not change. In relation to $\mathrm{Zn}$, mahogany leaves showed the lowest contents regardless of the light environment (Table 3). The mean value was ( $\left.15.29 \mathrm{mg} \mathrm{kg}^{-1}\right), 24 \%$ lower than that found in tonka bean $\left(20.13 \mathrm{mg} \mathrm{kg}^{-1}\right)$. Through a carefully nutrient analysis, mahogany leaves showed higher phosphorus concentration regardless the light environments (Table 2), while lower values for $\mathrm{Zn}$ (Table 3). This results suggest the classic antagonism between P and Zn (Marschner, 1995). In this respect, there are doubts and controversies whether or not phosphorus induced $\mathrm{Zn}$ deficiency by observing a decrease of $\mathrm{Zn}$ concentration in above ground biomass.

\section{CONCLUSION}

We conclude that mahogany leaves had the best performance under full sunlight in spite of its growth under shade. Whereas, differences in the parameters analyzed were not observed in tonka bean. This fact demonstrates the lower plasticity in comparison to mahogany leaves for growth allometry. In relation to nutrients, the highest nitrogen, potassium, iron and manganese contents may have contributed to final leaf size in mahogany grown in sun environments. However, inter-specific comparison showed greater phosphorus and calcium contents in mahogany leaves and $\mathrm{Zn}$ and $\mathrm{Mn}$ in tonka bean leaves, regardless of the light environments. Finally, we hypothesized that late-successional species are less plastic than mid-successional species. We found that it is true that mahogany is a mid-successional species; its leaves showed greater plasticity for leaf growth allometry than tonka bean. For leaf nutrient content, both species have changed in relation to light environments.

\section{ACKNOWLEDGEMENTS}

The study was supported by the Brazilian Ministry of Science and Technology and the Brazilian Amazon Forest Research Project (Phase II, Project n ${ }^{\circ}: 309-1064$ - E - 1) - The Japanese International Cooperation Agency.

\section{LITERATURE CITED}

Bazzaz, F.A. 1979. The physiological ecology of plant succession. Annual Review of Ecology and Systematics, 10: 351-71.

Bongers, F. Popma, J. and Iriarti-Vivar, S. 1988. Response of Cordia megalantha Blake seedlings to gap environments in tropical rain forest. Functional Ecology, 2: 379-90

Bushbacher, R.J. 1990. Ecological analysis of natural forest management in the humid tropic. In: Goodland, R. (Editor). Race to save the tropics. Island Press, Washington, DC. p. 57-79.

Fearnside, P. M. 1999. Biodiversity as an environmental service in Brazil's amazonian Forest: risk, value and conservation. Environmental conservation, 26:305-321.

Ferraz, J.; Sales, P. C.; Ohta, S.; Takahashi, M.; Hirai, K.; Kobayashi, M.; Silva, C. E. M. da; Mendonça, A. P.; Costa, D. C. 2000. Estudos para manejo florestal e recuperação de áreas degradadas: Características dos sítios. Workshop Intermediário do Projeto Jacaranda. 19 de setembro de 2000, Manaus/AM. p. 16-17.

Gillespie, A. R.; Chaney, W. R. 1989. Process modelling of nitrogen effects on carbon assimilation and allocation - a review. Tree Physiology, 5: 99 - 112.

Gonçalves, J. F. C., Marenco, R. A., Vieira, G. 2001. Concentrations of photosynthetic pigments and chlorophyll fluorescence of Swietenia macrophylla king and Dipteryx odorata Aubl. Willd. under two light environments. Brazilian Journal of Plant Phisiology, 13(2): 149-157.

INPE, Instituto Nacional de Pesquisas Espaciais. 2003. http: www.inpe.br / amazonia.htm

Laurance, W. F.; Cochrane, M. A., Bergen, S.; Fearnside, P.M.; Delamonica, P.; Barber, C.; D’Angelo, S.; Fernandes, T. 2001. The future of Brazilian Amazon. Science, 291:438-439.

Lorenzi, H. 1998. Árvores brasileiras: manual de identificação e cultivo de plantas arbóreas nativas do Brasil. Plantarum, Nova Odessa, SP, Brasil. 368 pp. 
Marenco, R. A.; Gonçalves, J.F.C.; Vieira, G. 2001. Leaf gas exchange and carbohydrates in tropical trees differing in successional status in two light environments in central Amazonian. Tree Physiology, 21: 1311-1318.

Marschner, H. 1995. Mineral nutrition of higher plants. 2.ed. San Diego: Academic Press, 902pp.

Miyazawa, M.; Pavan, M. A.; Muraoka, T.; Carmo, C. A. F. S.; Mello, W. J. 1999. Análises químicas de tecido vegetal. In: Silva, F. C. (Org). Manual de analises químicas de solos, plantas e fertilizantes. Empresa Brasileira de Pesquisa Agropecuária. Brasília, DF. P. 172-223.

Murphy, J.; Riley, J. P. 1965. A modified single solution method for estimation of phosphate in natural matters. Analytical Chemistry Acta, 27: 3-36.

Nepstad, D. C.; Veríssimo, A.; Alencar, A., Nobre, C.; Lima, E., Lefebvre, P.; Schlesinger, P.; Potter, C.; Moutinho, P.; Mendoza, E.; Cochrane, M.; Brooks, V. 1999. Large-scale impoverishment of Amazonian forests by logging and fire. Nature. 398: 505-508.

Neves, E. J. M.; Reissmann, C. B.; Ferreira, C. A; Bellote, A. F. J.; Dunisch, O. 1999. Nutritional status of Ceiba pentandra (L.) GAERTN. and Virola surinamensis (Rol.) Warb. Growing on poor soils in the Bazilian Amazon Region. BFH Mitteilungen. 193: 71-77.

Ribeiro, J.E.L.S.; Hopikins, M.J.G.; Vicentini, A.; Sothers, C.A.; Costa, M.A.S.; Brito, J.M.; Souza, M.A.D.; Martins, L.H.P.; Lohmann, L.G.; Assunção, P.A.C.L.; Pereira, E.C.; Silva, C.F.; Mesquita, M.R.; Procópio, L.C. 1999. Flora da Reserva Ducke. Guia de identificação das plantas vasculares de uma floresta de terra-firme na Amazônia Central. INPADFID, Manaus, Brasil. 816 pp.
Serigato, E. M. 2000. Fatores do solo, estado nutricional e crescimento de plantios de teca (Tectona grandis L. f.) no norte de Mato Grosso. Dissertação de Mestrado, Instituto Nacional de Pesquisas da Amazônia. Manaus, Amazonas. 108pp.

Silva, D. J. 2000. Estado nutricional, crescimento de teca (Tectona grandis L.f.) e suas relações com os fatores de sítio do solo em plantios no sudoeste de Mato Grosso. Dissertação de Mestrado, Instituto Nacional de Pesquisas da Amazônia. Manaus, Amazonas. 115pp.

Schmidt, P.; Lieberei, R.; Bauch, J.; Gasparotto, L. 1999. Biomass production and mineral element content of Swietenia macrophylla King in the juvenile phase under plantation conditions in central Amazon. BFH Mitteilungen. 193, 61-70.

Schulze, E. D. 1986. Carbon dioxide and water vapor exchange in response to drought in the atmosphere and in the soil. Annual Review of Plant Physiology 37, 247-274.

Turner, N. C.; Jones, M. M. 1980. Turgor maintenance by osmotic adjustment: a review and evaluation. In: N. C. Turner; P. J. Kramer (eds). Adaptation of plants to water and bigh temperature stress. Wiley, New York. P.87-103.

Vieira, G. 1996. Gap dynamics in maneged Amazonian Forest: structural and ecophysiological aspects. PhD. Thesis. Oxford, University of Oxford. 162 pp.

\section{RECEBIDO EM 16/08/2001 \\ ACEITO EM 26/11/2004}


